\title{
Frequency of renal impairment in paracetamol overdose compared with other causes of acute liver damage
}

\author{
S. P. WILKINSON, HELEN MOODIE, V. A. ARROYO, AND \\ ROGER WILLIAMS
}

From the Liver Unit, King's College Hospital and Medical School, Denmark Hill, London SE5

SUMMARY In an analysis of 160 patients with fulminant hepatic failure, the frequency of renal failure in the patients who had taken an overdose of paracetamol was not significantly higher than in those with hepatic failure due to other causes. The same was found in another group of patients with less severe hepatic damage. In both the latter group and the patients with fulminant hepatic failure, the development of renal failure was closely related to the occurrence of endotoxaemia as detected by the Limulus lysate assay. These findings do not support the concept that an overdose of paracetamol has a specific nephrotoxic effect.

The hepatotoxicity of an acute overdose of paracetamol (Acetaminophen) is now well known (Davidson and Eastham, 1966; Clark et al., 1973) and renal failure has also been reported in these patients. Whether or not the renal failure is due to a direct nephrotoxic effect of paracetamol, or is in some way secondary to the hepatic failure, has been a subject of considerable debate (Dixon, 1976; Chenery et al., 1976) for renal failure is also frequently found in fulminant hepatic failure due to other causes (Wilkinson et al., 1974b). In one series of 280 patients who had taken an overdose of paracetamol, isolated renal failure in the absence of severe liver damage was not seen (Lesna et al., 1976). Ingestion of the parent compound, phenacetin, over a long period is a well recognised cause of chronic renal failure, but this has been reported only rarely following chronic ingestion of paracetamol (Krikler, 1967; Edwards et al., 1971).

To try to resolve this question, we have analysed the frequency of renal failure in 160 patients with fulminant hepatic failure and grade IV encephalopathy separated according to aetiology. The frequency of renal failure in 90 cases of paracetamol overdose with less severe hepatic damage was also compared with that found in 100 cases of acute viral hepatitis with comparable abnormalities in liver function tests. Finally, in view of the close relationship previously reported between the development of renal failure and the occurrence of endotoxaemia (Wilkinson et al., 1974a), we have carried out assays for endotoxin in a representative group of patients with a paracetamol overdose.

\section{Methods}

The Limulus lysate method of Levin and Bang was used to detect systemic endotoxaemia as previously described (Wilkinson et al., 1974a), the plasma inhibitor of the gel reaction being removed by chloroform extraction. All samples were tested with the same batch of lysate, the sensitivity of which was $\geqslant 1 \mathrm{ng} / \mathrm{ml}$ for standard endotoxin (Difco $0111: \mathrm{B} 4$ ) added to healthy human plasma.

\section{Results}

In the analysis of 160 patients with fulminant hepatic failure, renal failure was considered present if the 24-hour urine volume was $\leqslant 300 \mathrm{ml}$ or the plasma creatinine concentration had risen to at least $0.4 \mathrm{mmol} / \mathrm{l}$. Patients in whom this had developed in the last 24 hours of life, in association with cardiac or respiratory arrest or severe terminal hypotension, were not included in this definition. Although the frequency of renal failure appeared to be higher in the patients with a paracetamol overdose $(53 \%)$ than in those with acute viral hepatitis $(38 \%)$, or when the hepatic failure was attributable to other causes $(38 \%)$, none of the differences achieved statistical 
significance (Table). There were also no statistically significant differences between survival rates in the different aetiological groups and the frequency with which renal failure occurred.

One hundred and twelve of the patients were admitted sufficiently early after the onset of their illness to determine the temporal relationship between onset of renal impairment and progression of liver failure. In $45 \%$ of the patients in the paracetamol group, evidence of renal failure was present before the patient's condition had deteriorated with loss of consciousness and other signs indicative of grade IV encephalopathy. This was more frequent than in either the viral hepatitis or miscellaneous groups (29\% and $24 \%$ respectively), but again the differences were not statistically significant $(P>0.4$, $>0.4$, respectively).

FREQUENCY OF RENAL FAILURE IN LESS SEVERE HEPATIC DAMAGE

In both groups there was a wide range of abnormalities in liver function tests. Serum bilirubin levels varied from $35-200$ and $115-710 \mu \mathrm{mol} / 1$ in the paracetamol and hepatitis patients respectively, corresponding values for aspartate aminotransferase being 170-2400 and 180-1900 iu/l. None of the patients had encephalopathy of more than grade I severity.

Evidence of renal failure, using the same criteria as in the group with fulminant hepatic failure, was present in $6(7 \%)$ of the 90 patients with a paracetamol overdose, and in $7(7 \%)$ of the 100 with viral hepatitis. In none of the cases of renal failure in either group was there an apparent factor precipitating its development, such as septicaemia or hypotension. Of the patients with renal failure one in each group died, in each instance as a result of septicaemia or other severe infections developing subsequently during the clinical course.

\section{RELATION OF RENAL FAILURE TO}

\section{ENDOTOXAEMIA}

Thirteen of 14 patients with fulminant hepatic failure from a paracetamol overdose, who had developed renal failure, had a positive Limulus assay, compared with only one of the seven tested who did not have renal failure $(P<0.001)$. In 21 patients with ful- minant hepatic failure due to other causes in whom the Limulus assay was performed, this was positive in all 12 with renal failure but negative in the other nine $(P<0.001)$. Similarly, of eight patients with less severe liver damage due to paracetamol, a positive assay was obtained in only the two patients with renal failure $(P=0.05)$. None of the patients in the paracetamol group with a positive Limulus assay had evidence of Gram-negative infections, on the basis of clinical findings and blood and urine cultures, at the time of investigation.

\section{Discussion}

The findings in the present study do not support the concept that paracetamol, taken in overdose, has a specific nephrotoxic action but do support the mechanism previously proposed that renal failure in fulminant hepatic failure, both when paracetamolinduced and from other causes, is related to endotoxaemia (Wilkinson et al., 1974a). Since the endotoxaemia was not associated with other evidence of Gram-negative infection, it is likely that this is due to failure of the liver to filter endotoxins normally absorbed from the bowel into the portal venous blood (Ravin et al., 1960).

The mechanism whereby endotoxin causes rena failure is almost certainly multifactorial and includes a direct renal vasoconstriction (Gillenwater et al., 1963) and intravascular coagulation, the latter possibly accounting for the tubular necrosis that is often found (Wardle, 1975). Although the specificity of the Limulus assay to detect endotoxins has been questioned-in particular it has been suggested that Gram-positive infections (Stumacher et al., 1973) and both thrombin and thromboplastins (Elin and Wolff, 1973) may result in 'false positives'-there is little support for these claims. Pure growths of Grampositive organisms have not been associated with positive reactions (Reinhold and Fine, 1971) and the positive results reported with thrombin and thromboplastin are almost certainly due to endotoxin contamination of the preparations used (Yin, 1975a and $b$ ).

Other more detailed studies of renal function, including measurements of the clearances of inulin

Table Occurrence of renal failure in patients with fulminant hepatic failure and grade IV encephalopathy

\begin{tabular}{|c|c|c|c|c|c|c|c|c|c|}
\hline & \multicolumn{3}{|c|}{ Total series } & \multicolumn{3}{|c|}{ Survivors } & \multicolumn{3}{|c|}{ Fatal cases } \\
\hline & No. & $\begin{array}{l}\text { No. with } \\
\text { renal failure }\end{array}$ & $P$ value & No. & $\begin{array}{l}\text { No. with } \\
\text { remal failure }\end{array}$ & $P$ value & No. & $\begin{array}{l}\text { No. with } \\
\text { renal failure }\end{array}$ & $P$ value ${ }^{1}$ \\
\hline Viral hepatitis & 68 & $26(38 \%)$ & \multirow{3}{*}{$\begin{array}{l}>0.05 \\
>0.05\end{array}$} & 14 & $4(29 \%)$ & \multirow{3}{*}{$\begin{array}{l}>0.1 \\
>0.1\end{array}$} & 54 & $22(41 \%)$ & \multirow{3}{*}{$\begin{array}{l}>0.05 \\
>0.05\end{array}$} \\
\hline Paracetamol overdose & 53 & $28(53 \%)$ & & 11 & $2(18 \%)$ & & 42 & $26(62 \%)$ & \\
\hline Others & 39 & $15(38 \%)$ & & 6 & $1(17 \%)$ & & 33 & $14(42 \%)$ & \\
\hline
\end{tabular}

Statistical analysis by Chi-square test 
para-aminohippurate, and free water, and electrolyte excretion have shown similar abnormalities in patients with paracetamol-induced fulminant hepatic failure compared to other causes (Wilkinson et al., 1976).

Animal studies have also failed to show that high doses of paracetamol have a significant nephrotoxic effect. In one study in rats, paracetamol, in contrast to other metabolites of phenacetin, failed to cause renal damage as assessed histologically (Calder et al., 1971). In a more detailed study, also in rats, paracetamol did not depress glomerular filtration rate or alter the capacity of the kidney for dilution, concentration, or acidification, but minor histological changes in the renal cortex and slight proteinuria were found, changes that were evidently not of functional significance (Peters et al., 1972).

We are indebted to the Department of Clinical Pathology for the liver function tests referred to in this paper, and to Sterling-Winthrop Group Ltd for their generous support.

\section{References}

Calder, I. C., Funder, C. C., Green, C. R., Ham, K. N., and Tange, J. D. (1971). Comparative nephrotoxicity of aspirin and phenacetin derivatives. British Medical Journal, 4, 518-521.

Chenery, R., Fisher, C., and McLean, A. E. M. (1976). Toxicity of paracetamol (Letter). Lancet, 1, 191.

Clark, R., Thompson, R. P. H., Borirakchanyavat, V., Widdop, B., Davidson, A. R., Goulding, R., and Williams, R. (1973). Hepatic damage and death from overdose of paracetamol. Lancet, 1, 66-70.

Davidson, D. G. D. and Eastham, W. N. (1966). Acute liver necrosis following overdose of paracetamol. British Medical Journal, 2, 497-499.

Dixon, M. F. (1976). Paracetamol hepatotoxicity. (Letter). Lancet, 1, 35.

Edwards, O. M., Edwards, P., Huskisson, E. C., and Taylor, R. T. (1971). Paracetamol and renal damage. British Medical Journal, 2, 87-89.

Elin, R. J. and Wolff, S. M. (1973). Nonspecificity of the Limulus amebocyte lysate test: positive reactions with polynucleotides and proteins. Journal of Infectious
Diseases, 128, 349-356.

Gillenwater, J. Y., Dooley, E. S., and Frohlich, E. D. (1963). Effects of endotoxin on renal function and hemodynamics. American Journal of Physiology, 205, 293-297.

Krikler, D. M. (1967). Paracetamol and the kidney. British Medical Journal, 2, 615-616.

Lesna, M., Watson, A. J., Douglas, A. P., Hamlyn, A. N., and James, O. (1976). Toxicity of paracetamol (Letter). Lancet, 1, 191.

Peters, G., Baechtold-Fowler, N., Bonjour, J. P., Chométy-Diézi, F., Filloux, B., Guidoux, R., Guignard, J. P., Peters-Haefeli, L., Roch-Ramel, F., Schelling, J. L., Hedinger, C., and Weber, E. (1972). General and renal toxicity of phenacetin, paracetamol, and some antimitotic agents in the rat. Archiv für Toxikologie, 28, 225-269.

Ravin, H. A., Rowley, D., Jenkins, C., and Fine, J. (1960). On the absorption of bacterial endotoxin from the gastro-intestinal tract of the normal and shocked animal. Journal of Experimental Medicine, 112, 783-792.

Reinhold, R. B. and Fine, J. (1971). A technique for quantitative measurement of endotoxin in human plasma. Proceedings of the Society for Experimental Biology and Medicine, 137, 334-340.

Stumacher, R. J., Kovnat, M. J., and McCabe, W. R. (1973). Limitations of the usefulness of the Limulus assay for endotoxin. New England Journal of Medicine, 288, $1261-1264$.

Wardle, E. N. (1975). Endotoxinaemia and the pathogenesis of acute renal failure. Quarterly Journal of Medicine, 44, 389-398.

Wilkinson, S. P., Arroyo, V. A., Gazzard, B. G., Moodie, H., and Williams, R. (1974a). Relation of renal impairment and haemorrhagic diathesis to endotoxaemia in fulminant hepatic failure. Lancet, $\mathbf{1}$, 521-524.

Wilkinson, S. P., Arroyo, V. A., Moodie, H., Blendis, L. M., and Williams, R. (1976). Abnormalities of sodium excretion and other disorders of renal function in fulminant hepatic failure. Gut, 17, 501-505.

Wilkinson, S. P., Blendis, L. M., and Williams, R. (1974b). Frequency and type of renal and electrolyte disorders in fulminant hepatic failure. British Medical Journal, 1, 186-189.

Yin, E. T. (1975a). Endotoxin, thrombin, and the Limulus amebocyte lysate test. Journal of Laboratory and Clinical Medicine, 86, 430-434.

Yin, E. T. (1975b). Personal communication. 